\title{
Study of Position, Shape, Size and Incidence of Mental Foramen and Accessory Mental Foramen in Indian Adult Human Skulls
}

\author{
Estudio de la Posición, Forma, Tamaño e Incidencia del Foramen Mentoniano \\ y Foramen Mentoniano Accesorio en Cráneos Humanos de Indios Adultos
}

Rajani Singh \& A. K. Srivastav

SINGH, R. \& SRIVASTAV, A. K. Study of position, shape, size and incidence of mental foramen and accessory mental foramen in Indian adult human skulls. Int. J. Morphol., 28(4):1141-1146, 2010.

SUMMARY: Paralysis of the mental nerve is one of the principal complications of surgery of the mandibular canal and mental foramen region. Therefore, identification of mental foramen is important for dental surgeons in nerve block and surgical procedures like apico curettage of mandibular premolars, amalgam filling, peridental surgery etc. to avoid injury to neurovascular bundle. Accessory mental foramina tend to exist in the apical area of the first molar and posterior or inferior area of the mental foramen. The accessory branches of the mandibular canal showed common characteristics in the course of gently sloping posterosuperior direction in the buccal surface area. Verification of the existence of accessory mental foramina would prevent accessory nerve injury during periapical surgery. In root canal treatment, the possibility of accessory mental foramina-related nerve paresthesia seems low unless the mental foramen and mandibular canal are injured. Therefore, prior surgical knowledge of morphology and morphometry of mental and accessory mental foramen peculiar to particular block may enable effective mental block anaesthesia. Besides this, as mental foramen and accessory mental foramen have been found to vary in position in different ethnic groups. So, it is important to study the morphology and morphometry of mental foramen and accessory mental foramen. Hence this study was carried out. Present study was conducted using dried adult human mandibles of both sexes. Size and position were determined using digital vernier callipers. Incidences and shapes of mental foramen and accessory mental foramen were also observed. Mental foramen was present in all one hundred observed mandibles and it is bilateral. Accessory mental foramen was present in 8 percent on left side while on right side, it was 5 percent. None of the mandibles presented with bilateral accessory mental foramen. Shape was predominantly round with 94 percent on right side and 87 percent on left side while it was oval in 6 percent on right side and 13 percent on left side.Average size of mental foramen was $2.79 \mathrm{~mm}$ on right side while it was $2.57 \mathrm{~mm}$ on left side. Average size of accessory mental foramen was $1.00 \mathrm{~mm}$ varying from $0.5 \mathrm{~mm}$ to $4.00 \mathrm{~mm}$. Mental foramen was located below the apex of second premolar in 68.8 percent mandibles while it is 17.8 percent between first and second premolars and in 11.5 percent, it is between second premolar and first molar. Accessory mental foramen lies $0.67 \mathrm{~mm}$ lateral to mental foramen and below the apex of first molar tooth.

KEY WORDS: Mental foramen; Accessory mental foramen; Mandible; Mental nerve; Premolar; Molar.

\section{INTRODUCTION}

Mental foramen (MF) is located in the body of mandible at an equal distance from the superior and inferior border Picosse (1982) and Marzola (1989). Normally, MF is located below the interval between the premolars. Mental nerve and vessels pass through MF. Variations in the position of MF have been analysed. It may lie between the apices of lower premolars, below the apex of second premolar. Data from various ethnic groups e.g. Tanzanian, Thai, Chinese, British, Saudi Arabian vary regarding the location of MF. A review by Green (1987) demonstrated a clear racial trend in the position of the MF.
Any foramen in addition to MF is known as accessory mental foramen (AMF) in the body of mandible. It is situated below the first molar tooth according to Cag irankaya \& Kansu (2008). The distances between MF and AMF in three cadavers were reported to be $0.67 \mathrm{~mm}, 2.1 \mathrm{~mm}$ and 5.74 $\mathrm{mm}$ Toh et al. (1992). Ethnic variations in relation to AMF have also been reported by Sawyer et al. (1998). Hence location, size, shape, position and incidence of MF and AMF would facilitate the dental surgeon to apply nerve block in different surgical procedures involving lower jaw. As AMF 
is due to branching of mental nerve before passing through MF, hence its shape size and verification of its existence would prevent Accessory nerve injury during periapical surgery. In addition to this, if this nerve is not blocked, in the structures supplied by it, parasthesia will be less.

\section{MATERIAL AND METHOD}

Present study was carried out using one hundred dried adult human mandibles of unknown sex in the Department of Anatomy, CSM Medical University Lucknow UP, India. Digital Vernier Callipers was used to measure the dimensions of MF and AMF to analyse and examine the size, shape and position of MF and AMF. The incidences of MF and AMF were also observed.

\section{RESULTS}

Position of mental foramen in relation to lower teeth. MF was situated below the apex of second premolar tooth in $68.8 \%$ mandibles whereas in $17.8 \%$ of mandibles it was observed between first and second premolars. In $11.5 \%$ it was found between second premolar and first molar and in $2.1 \%$ it was seen below the apex of first premolar. In Figure 1, MF is lying between first and second premolar on left side and below the apex of second premolar on right side. Position of MF in relation to various parameters has been described in Table I.

Position of accessory mental foramen in relation to lower teeth (Figs. $2 \& 3$ ).

Position of AMF in 8 mandibles out of 100 was found situated below apex of first molar tooth whereas it was observed to be located between first and second premolar in 5 mandibles out of the same 100. Average distance between MF and AMF was $0.67 \mathrm{~mm}$ lateral to MF.

Shape of MF. On right side it is oval in $6 \%$ of mandibles and round in $94 \%$ of mandibles. On left side it is oval in $13 \%$ of mandibles while it is round in $87 \%$ of mandibles.

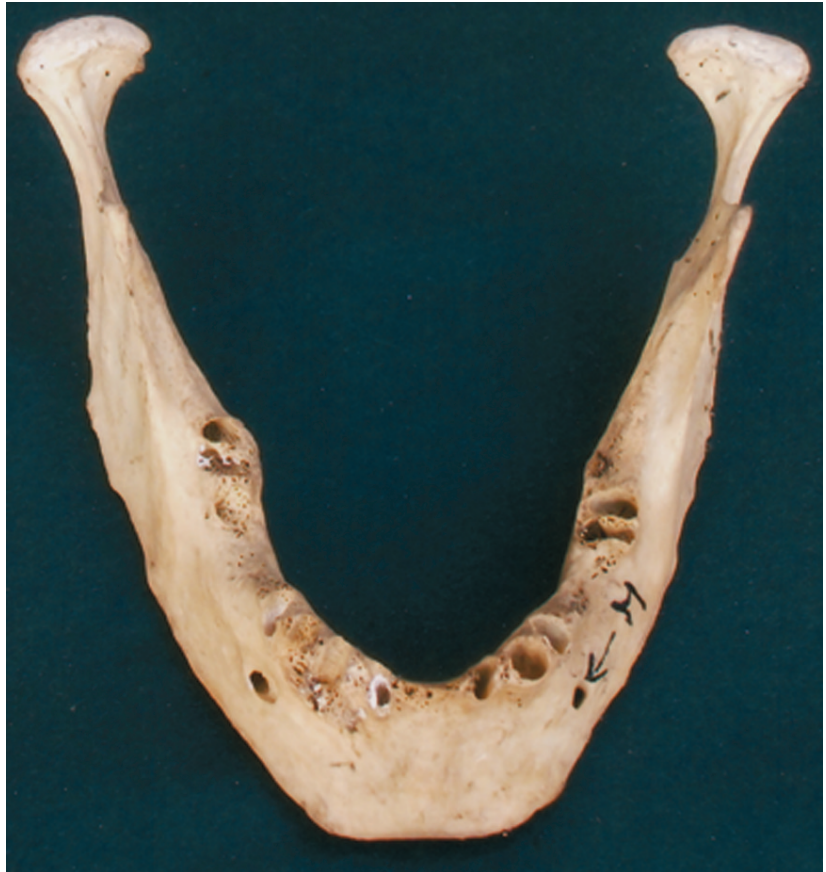

Fig. 1. Position of mental foramen in relation to lower teeth,

Size of MF. On right side: Average size was $2.79 \mathrm{~mm}$. Minimum size is $1 \mathrm{~mm}$ and Maximum size is $5 \mathrm{~mm}$.

On left side: Average size is $2.57 \mathrm{~mm}$. Minimum size is $1 \mathrm{~mm}$ and Maximum size is $6 \mathrm{~mm}$.

Size of AMF. Average size is $1 \mathrm{~mm}$. Minimum size is 0.6 $\mathrm{mm}$ and Maximum size is $1.5 \mathrm{~mm}$.

Incidences of MF. MF is present in all one hundred observed mandibles and it is bilateral.

Incidences of AMF. AMF is observed in 13 mandibles out of 100 mandibles. AMF was situated in 5 out of 13 mandibles on right side and in 8 out of the same13 mandibles in left side. Thus out of total population of 100 mandibles, AMF was found in right side of the body of mandibles in $5 \%$ while in left side it was present in $8 \%$ of the population under study.

None of the mandibles presented with bilateral accessory mental foramen.

Table- Position of mental foramen from various parametrs.

\begin{tabular}{llcc}
\hline & Parameters & $\begin{array}{c}\text { Mean of distances of MF from } \\
\text { parameters in right side: in cm }\end{array}$ & $\begin{array}{c}\text { Mean of distances of MF from } \\
\text { parameters in left side: in cm }\end{array}$ \\
\hline 1 & Symphysis menti & 2.93 & 3.06 \\
2 & Posterior margin of ramus of mandible & 7.18 & 8.47 \\
3 & Alveolar crest & 1.70 & 1.86 \\
4 & Base of mandible & 1.73 & 1.37 \\
\hline
\end{tabular}




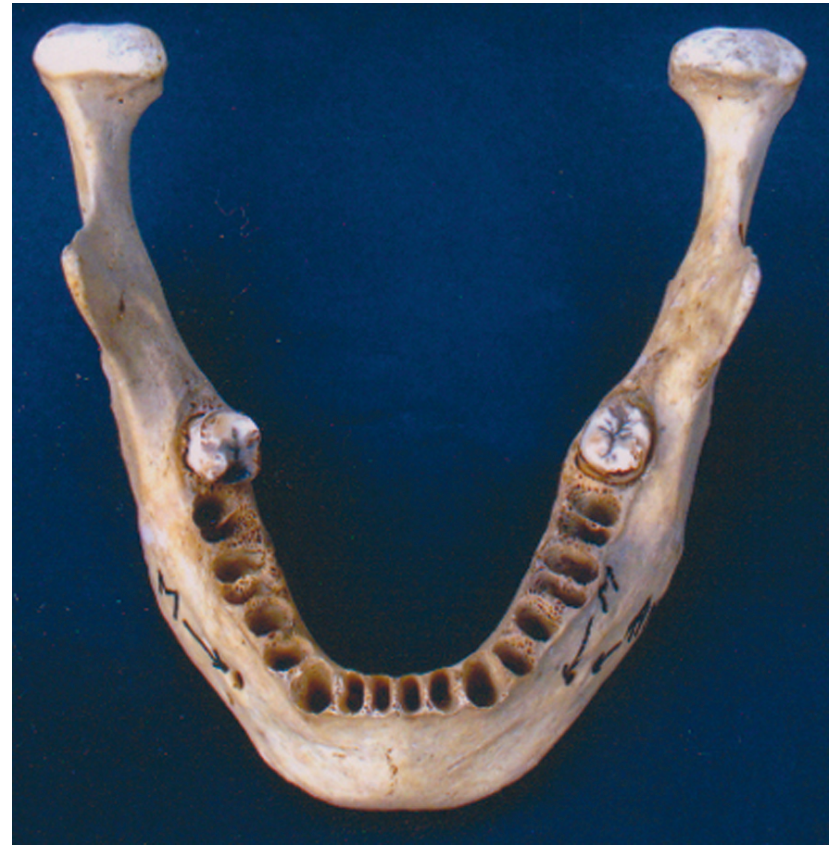

Fig. 3. Position of accessory mental foramen on left side along with mental foramen.

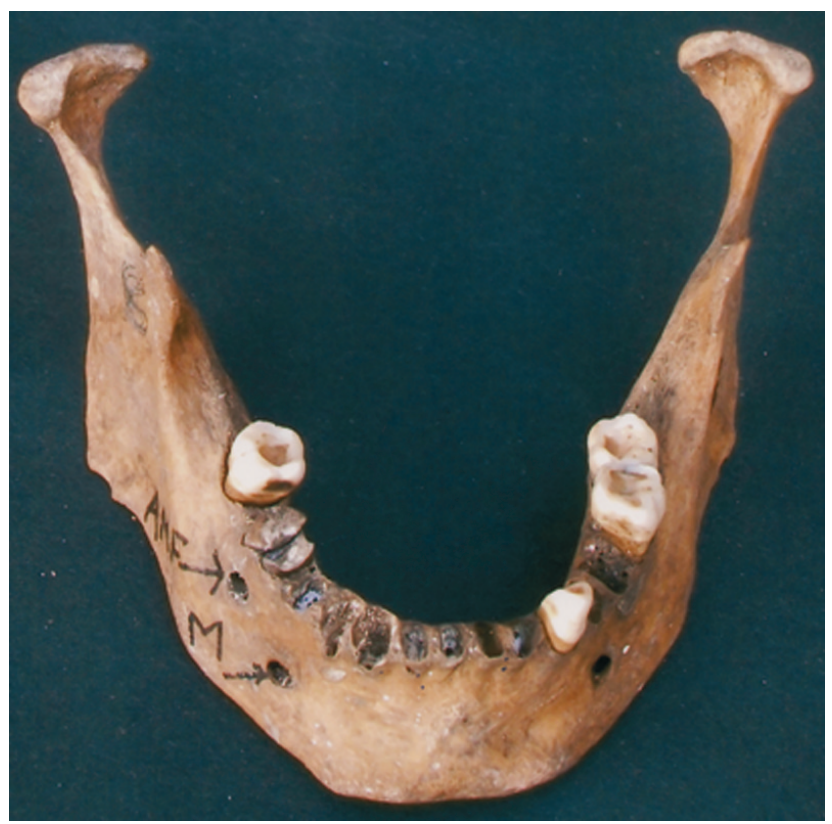

Fig. 4. Position of accessory mental foramen on right side along with bilateral mental foramen.

\section{DISCUSSION}

Position of the mental foramen. In the present study, most common position of MF is below the apex of second premolar tooth in $68.8 \%$ of Indian mandibles. In British mandibles, it was between first and second premolars in 65\% mandibles.
Its position below the apex of second premolar was $49 \%$ by Tebo \& Telford (1950), $58.98 \%$ by Wang et al. (1986) and 52.9\% Santini \& Land (1990).

Santini \& Land, Lockhart et al. (1983) and Aktebin et al. (2003) mentioned that MF is located between the apices of two premolars. But, according to Gardner et al. (1988), Bennet (1989), Dangelo \& Fattini (1991), usual position of foramen is below crown of second premolar. Such position has not been observed by the authors in the present study.

According to Phillips et al. (1992), Mwaniki \& Hassanali (1992), Ngeow \& Yuzawati (2003), Smajilagic \& Dilberovic (2004) and Apinhasmit et al. (2006), it was under the apex of first premolar. According to Phillips et al., the most common position of mental foramen was inferior to crown of second premolar which is similar to present study while according to Olasoji et al. (2004), most frequent position of MF was found between $1^{\text {st }}$ and $2^{\text {nd }}$ premolars, followed by the apical position of $2^{\text {nd }}$ premolar.

Ratios of distances from symphysis menti and posterior border of ramus of mandibles to the MF is 1:3.2 in present study as compared to 1:2.6 in adult Chinese mandibles by Wang et al. and 1:2.7 in British mandibles by Santini \& Land. Wang et al. showed that the distance between MF and symphysis menti was $28.06 \mathrm{~mm}$, between MF and posterior border of ramus of mandible was $74.14 \mathrm{~mm}$ and between the MF and base of mandible was $14.70 \mathrm{~mm}$. According to Marzola \& Freitas (2006), MF was between $13 \mathrm{~mm}-15 \mathrm{~mm}$ from the base of mandible. Souaga et al. (2004) studied 61 dry mandibles and found that MF was $14.89 \mathrm{~mm}$ above the base of mandible and $16.16 \mathrm{~mm}$ below the alveolar ridge in males while in females MF was $14.21 \mathrm{~mm}$ above the base of mandible and $15.66 \mathrm{~mm}$ below the alveolar ridge.

According to Yes, ilyurt et al. (2008), the mean distance between symphysis menti and MF on right side was $19.18 \mathrm{~mm}$ while on left side it was $19.37 \mathrm{~mm}$. Mean distance between MF and posterior border of ramus of mandible on right side was $48.58 \mathrm{~mm}$ and on left side it was $48.27 \mathrm{~mm}$.

Position of the accessory mental foramen. Cag irankaya \& Kansu reported that AMF below the first molar which is similar to the present study. Much literature is not available on the position of AMF in relation to teeth in India. According to Toh et al., distance between the MF and AMF in three cadavers are $0.67 \mathrm{~mm}, 2.1 \mathrm{~mm}$ and $5.74 \mathrm{~mm}$ whereas the authors observed position of AMF from MF to be $0.67 \mathrm{~mm}$.

Shape of the mental foramen. In the present study, on right side it is oval in $6 \%$ of mandibles and round in $94 \%$. In left side it is oval in $13 \%$ of mandibles whereas it is round in $87 \%$. 
According to Mbajiorgu et al. (1998), in 32 mandibles of black adults from Zimbabwe, MF was round in 14 mandibles (43.8\%) and oval in 18 mandibles (56.3\%). Oliveira Junior et al. (2009) reported that the shape was oval in 59 mandibles (73.8\%) on right side and 57 mandibles $(71.3 \%)$ on left side. Larger diameter in the horizontal direction was found in $98.3 \%$ of the above mandibles on the right side and only $1.7 \%$ being the larger diameter in vertical direction. On left side all oval foramina were having larger horizontal diameter. Round shape was in 21 mandibles (26.2\%) on right side while in 23 mandibles (28.7\%) on left side. According to Al-khateeb et al. (2007), the majority of foramina were round in shape similar to the present study.

Size of the mental foramen. According to Chung et al. (1995), horizontal opening of MF was $2.4 \mathrm{~mm}$ and Apinhasmit $e t$ al. reported the average horizontal opening was $2.8 \mathrm{~mm}$. Oguz \& Bozkir (2002) did measurements in 34 dry mandibles of people from Turkey. The horizontal dimension of MF was $2.93 \mathrm{~mm}$ on right side and $3.14 \mathrm{~mm}$ on left side. The vertical dimension was $2.38 \mathrm{~mm}$ and 2.64 $\mathrm{mm}$ on right and left sides respectively. Souaga et al. studied 61 dry mandibles. The average sizes of long and short axes of foramina were $5.66 \mathrm{~mm}$ and $3.97 \mathrm{~mm}$ in mandibles while dimensions of female mandibles were $4.99 \mathrm{~mm}$ and 3.87 $\mathrm{mm}$.

The present observations brought out average horizontal dimension of MF to be $2.79 \mathrm{~mm}$ on right side and $2.57 \mathrm{~mm}$ on the left side.

Size of the accessory mental foramen. In the present study, the average dimension of AMF is $1 \mathrm{~mm}$. Published literature related to the size of AMF for common scholars is hardly available.

Incidence of the mental foramen. In the observations under this study, MF was present in all the 100 mandibles (100\%) and it was bilateral. Oliveira Junior et al. analysed 80 mandibles and established $100 \%$ presence of MFs. de Frietas et al. (1979) reported 0.4\% absence of MFs.

Incidence of the accessory mental foramen. In the present study AMF was present in 13 mandibles (13\%) out of 100. $8 \%$ of total 100 mandibles were found on left side and $5 \%$ on right side. Thus, $67 \%$ of total incidences of AMF (13) were observed in left side and rest $33 \%$ in right side.

According to Gershenson et al. (1986), AMF was present in $2.8 \%$ Israeli adults' mandibles. It is $1.8 \%$ for American whites and $12.5 \%$ in Polinesians. Oliveira Junior et al. reported 5\% AMF in mandibles. Highest incidences of AMFs were reported in Negros and Maori males. The incidences of AMFs did not differ significantly between right and left side of the mandibles.

In conclusion, the present analysis revealed variations in position, shape and size of MF and AMF. This may be related to feeding habits of different regions which may ultimately, effect the development of mandibles. The variability of the position of MF and AMF should alert the dental surgeons while performing periodontal or endodontic surgery.

AMF is found due to branching of mental nerve prior to its passing through the mental foramen. Thus, verification of existence of AMF would prevent accessory nerve injury during periapical surgery. In root canal treatment, possibility of AMF related paraesthesia will be less. Besides this, further if the studies are carried out in large volumes related to variation in the position, size, incidence and shape of MF and AMF it will be of immense use to the anthropologists in identifying the deceased.

\section{ACKNOWLEDGEMENTS}

Authors are thankful to Dr. Navneet Kumar for his valuable suggestions from time to time. Thanks are also due to Dr. Anita Rani for her kind help in facilitating the preparation of publication. Authors are grateful to the Department of Anatomy, CSM Medical University Lucknow, UP, India and concerned employees for providing necessary material for present study. Last but not the least Mr. Man Singh, father of Dr. Rajani Singh, one of the authors deserve sincere thanks for encouragement and assistance in preparing the article.

SINGH, R. \& SRIVASTAV, A. K. Estudio de la posición, forma, tamaño e incidencia del foramen mentoniano y foramen mentoniano accesorio en cráneos humanos de Indios adultos. Int. J. Morphol., 28(4):1141-1146, 2010.

RESUMEN: La parálisis del nervio mentoniano es una de las principales complicaciones de la cirugía del canal mandibular y la región del foramen mentoniano. Por lo tanto, la identificación del foramen mentoniano es de gran importancia para cirujanos dentistas en el bloqueo del nervio y los procedimientos quirúrgicos como el legrado ápical de premolares inferiores, obturación de amalgamas, la cirugía periodental, etc., a fin de evitar lesiones del paquete neurovascular. Los forámenes mentonianos accesorios tienden a existir en la zona apical del primer molar y la zona posterior o inferior del foramen mentoniano. Las ramas accesorios del canal mandibular presentan características comunes en el curso de la leve pendiente de dirección posterosuperior de la superficie bucal. Verificar la existencia de forámenes mentales accesorios evitaría la lesión del nervio accesorio durante la cirugía periapical. En el tra- 
tamiento del canal radicular, la posibilidad parestesia relacionada con daño de los forámenes mentonianos accesorios es baja a menos que el foramen mentoniano y el canal mandibular se lesionen. El conocimiento de la morfología y la morfometría del foramen mentoniano y los forámenes mentonianos accesorios puede permitir un efectivo bloqueo anestésico mentoniano, y es fundamental previo a una cirugía. Además de esto, se ha encontrado que los forámenes varían en su posición en diferentes grupos étnicos, siendo importante estudiar su morfología y morfometría. Se realizó el estudio sobre mandíbulas humanas adultas secas, de ambos sexos. El tamaño y la posición de los forámenes se determinaron utilizando calipers digitales. La incidencia y la forma del foramen mentoniano y forámenes mentales accesorios también fueron observados. El foramen mentoniano estaba presente en las 100 mandíbulas observadas, y fueron bilaterales. Forámenes mentales accesorios estaban presente en un $8 \%$ en el lado izquierdo, mientras que en el lado derecho, un 5\%. Ninguna de las mandíbulas presentó formanes accesorios bilaterales. La forma era predominantemente redonda, $94 \%$ lado derecho y $87 \%$ lado izquierdo, mientras que ovalada se observó $6 \%$ lado derecho y $13 \%$ lado izquierdo. El tamaño promedio de foramen mentoniano fue de $2,79 \mathrm{~mm}$ en el lado derecho, mientras que $2,57 \mathrm{~mm}$ en el lado izquierdo. El tamaño promedio de los forámenes accesorios fue 1,00mm (rango 0,54,00 mm). El Foramen mental se ubicó por debajo del ápice del segundo premolar en un $68,8 \%$, entre el primer y segundo premolar $17,8 \%$ y en el $11,5 \%$ se encuentró entre segundo premolar y primer molar. Los forámenes accesorios se ubicaron $0,67 \mathrm{~mm}$ lateral al foramen mentoniano y por debajo del ápice del primer molar.

PALABRAS CLAVE: Foramen mentoniano; Foramen mentoniano accesorio; Mandíbula; Nervio mentoniano; Premolares; Molares.

\section{REFERENCES}

Aktekin, M.; Celik, H. M.; Celik, H. H.; Aldur, M. M. \& Aksit, M. D. Studies on the location of the mental foramen in Turkish mandibles. Morphologie, 87:17-9, 2003.

Al-Khateeb, T.; Al-Hadi Hamasha, A. \& Ababneh, K. T. Position of the mental foramen in a northern regional Jordanian population. Surg. Radiol. Anat., 29:231-7, 2007.

Apinhasmit, W.; Methathrathip, D.; Chompoopong, S. \& Sangvichien, S. Mental foramen in Thais: an anatomical variation related to gender and side. Surg. Radiol. Anat., 28:529-33, 2006.

Bennet, C. R. Monheim. Anestesia Local e Controle da Dor na Prática Dentaria. $7^{\mathrm{a}}$ ed. Rio de Janeiro, Guanabara Koogan, 1989.

Cag irankaya, L. B. \& Kansu, H. An accessory mental foramen: a case report. J. Contemp. Dent. Pract., 9:98-104, 2008.
Chung, M. S.; Kim, H. J.; Kang, H. S. \& Chung, I. H. Locational relationship of the supraorbital notch or foramen and infraorbital and mental foramina in Koreans. Acta Anat. (Basel), 154:162-6, 1995.

Dangelo, J. G. \& Fattini, C. A. Anatomía Básica dos Sistemas Humanos. São Paulo, Atheneu, 1991.

de Freitas, V.; Madeira, M. C; Pinto, C. T. \& Zorzetto, N. L. Direction of the mental canal in human mandibles. Aust. Dent. J., 21:338-40, 1976.

Freitas, R. Tratado de Cirurgia Buco-Maxilo-Facial. São Paulo, Santos, 2006.

Gardner, E.; Gray, D. J. \& O'hailly, R. Anatomía. 4ª ed. Rio de Janeiro, Guanabara Koogan, 1988.

Gershenson, A.; Nathan, H. \& Luchansky, E. Mental foramen and mental nerve: changes with age. Acta Anat. (Basel), 126:21-8, 1986.

Green, R. M. The position of the mental foramen: a comparison between the southern (Hong Kong) Chinese and other ethnic and racial groups. Oral Surg. Oral Med. Oral Pathol., 63:281-90, 1987.

Lockhart, R. D.; Hamilton, G. G. \& Fyfe, F. W. Anatomía do Corpo Humano. $2^{\text {a }}$ ed. Rio de Janeiro, Guanabara Koogan, 1983.

Marzola, C. Anestesiología. 1ª ed. São Paulo, Pancast Editorial, 1989.

Mbajiorgu, E. E.; Mawera, G.; Ásala, S. A. \& Zivanovic, S. Position of the mental foramen in adult black Zimbabwean mandibles: a clinical anatomical study. Cent. Afr. J. Med, 44:24-30, 1998.

Mwaniki, D. L. \& Hassanali, J. The position of mandibular and mental foramina in Kenyan African mandibles. East Afr. Med. J., 69:210-3, 1992.

Ngeow, W. C. \& Yuzawati, Y. The location of the mental foramen in a selected Malay population.J. Oral Sci., 45:171-5, 2003.

Oguz, O. \& Bozkir, M. G. Evaluation of location of mandibular and mental foramina in dry, young, adult human male, dentulous mandibles. West Indian Med. J., 51:14-6,2002.

Olasoji, H. O.; Tahir, A.; Ekanem, A. U. \& Abubakar, A. A. 
Radiographic and anatomic locations of mental foramen in northern Nigerian adults. Niger. Postgrad. Med. J., $11: 230-3,2004$.

Oliveira Junior, E. M.; Araújo, A. L. D.; Da Silva, C. M. F.; Sousa-Rodrigues, C. F. \& Lima, F. J. C. Morphological and morphometric study of the mental foramen on the M-CP-18 Jiachenjiang point. Int. J. Morphol., 27:2318, 2009.

Phillips, J. L.; Weller, R. N. \& Kulild, J. C. The mental foramen: 2. Radiographic position in relation to the mandibular second premolar. J. Endod., 18:271-4, 1992.

Picosse, M. Tratado de Anatomia Humana. $2^{\text {a }}$ ed. Rio de Janeiro, Editora Interamericana, 1982.

Santini, A. \& Land, M. A comparison of the position of the mental foramen in Chinese and British mandibles. Acta Anat. (Basel), 137:20S-12, 1990.

Sawyer, D. R.; Kiely, M. L. \& Pyle, M. A. The frequency of accessory mental foramina in four ethnic groups. Arch. Oral Biol., 43:417-20, 1998.

Smajilagic, A. \& Dilberovic, F. Clinical and anatomy study of the human mental foramen. Bosn. J. Basic Med. Set, 4:15-23, 2004.

Souaga, K.; Adou, A. \& Angoh, Y. Topographical and morphological study of the mandibular foramen in black Africans from the Ivory Coast. Odontostomatol. Trop., 27:17-21, 2004.

Tebo, H. G. \& Telford, I. R. An analysis of the variations in position of the mental foramen. Anat. Rec., 107:61-6, 1950.

Toh, H.; Kodama, J.; Yanagisako, M. \& Ohmori, T. Anatomical study of the accessory mental foramen and the distribution of its nerve. Okajimas Folia Anat. Jpn., 69:85-8, 1992.

Wang, T. M.; Shih, C.; Liu, J. C. \& Kuo, K. J. A clinical and anatomical study of the location of the mental foramen in adult Chinese mandibles. Acta Anat. (Basel), 126:2933, 1986.

Yes,ilyurt, H.; Aydinlioglu, A.; Kavakli, A.; Ekinci, N.; Eroglu, C.; Hacialiogullari, M. \& Diyarbakirli, S. Local differences in the position of the mental foramen. Folia Morphol., 67:32-5, 2008.

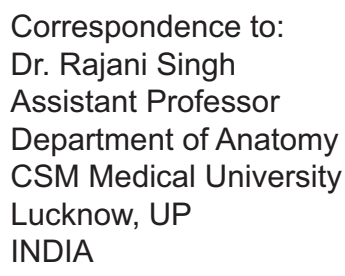

Email: nani_sahayal@rediffmail.com

Received: 16-02-1010

Accepted: 16-03-2010 